Asian-Australasian Journal of

Bioscience and Biotechnology

ISSN 2414-1283 (Print) 2414-6293 (Online)

www.ebupress.com/journal/aajbb

\title{
Article \\ Effects of different dietary energy and protein levels on the performance and carcass characteristics of native hilly chicken during growing phase in confinement
}

\author{
Halima Khatun $^{1 *}$, Shakila Faruqe ${ }^{1}$ and Md. Golam Mostafa ${ }^{2}$ \\ ${ }^{1}$ Poultry Production Research Division, Bangladesh Livestock Research Institute, Savar, Dhaka-1341, \\ Bangladesh \\ ${ }^{2}$ Jahangirnagar University, Savar, Dhaka, Bangladesh
}

*Corresponding author: Halima Khatun, Senior Scientific Officer, Poultry Production Research Division, Bangladesh Livestock Research Institute, Savar, Dhaka-1341, Bangladesh. E-mail: hkr.7519@gmail.com

Received: 08 March 2021/Accepted: 15 April 2021/ Published: 30 April 2021

\begin{abstract}
Two hundred and sixteen 10 weeks of age hilly chickens were used to determine the effects of dietary energy and protein level on growth performance, carcass characteristics and meat quality. The chicks were randomly allotted in to $3 \times 3$ factorial in a completely randomize design. Three levels of energy (2600, 2700 and $2800 \mathrm{ME} \mathrm{kcal} / \mathrm{kg}$ ) and three levels of dietary proteins $(16,17$ and $18 \% \mathrm{CP})$ were offered ad libitum to the chicks from 10-16 weeks of age. There were no significant interaction effect between dietary protein and energy levels in the diets. At 10-16 weeks of age hilly chickens fed with the medium protein diet (17\% CP) showed shortened feed intake $(\mathrm{p}<0.001)$ but FCR found better in $16 \%$ CP diet. Dietary protein levels higher than $16 \%$ CP did not show any significant effect on growth performance. However hilly chicken fed with lower protein diet converted protein to body weight and body weight gain more efficiently than those fed higher protein diets. Dietary energy contents of 2600,2700 and $2800 \mathrm{ME} \mathrm{kcal} / \mathrm{kg}$ did not affect the growth performance of hilly chicken except ME, CP intake and protein conversion ratio. ME and CP intake was increased with increasing dietary ME and CP levels $(\mathrm{p}<0.000)$. Protein utilization was better $(\mathrm{p}<0.05)$ in higher $(2800 \mathrm{ME} \mathrm{kcal} / \mathrm{kg})$ and medium $\left(2700 \mathrm{ME} \mathrm{kcal} / \mathrm{kg}\right.$ ) ME level diet. $\mathrm{L}^{*}, \mathrm{a}^{*}$ and $\mathrm{b}^{*}$ of breast meat was not affected by dietary ME and CP $(p>0.05)$. Dietary energy and protein level did not significantly $(\mathrm{p}>0.05)$ affect the drip loss, cooking loss and $\mathrm{pH}$ of breast meat between the treatments. Based on the data of growth performance, carcass characteristics and meat quality, the optimal dietary ME requirement of hilly chicken from 10-16 weeks of age is $2800 \mathrm{ME} \mathrm{kcal} / \mathrm{kg}$ and the $\mathrm{CP}$ requirement is $16 \%$.
\end{abstract}

Keywords: nutrients; native chicken; energy; protein; carcass characteristics

\section{Introduction}

Indigenous or local chicken are an important source of animal protein in the form of meat and eggs. In most developing countries, Bangladesh there is an emergent need for improving animal and poultry production to meet ongoing demand on animal protein. In Bangladesh hilly chicken is one of the modern developed genotype of native chicken for the production of meat. Hilly chicken was found the hill tract area of Bangladesh but spread all over the country. Few decades ago Bangladesh Livestock Research Institute (BLRI) has initiated to develop the genotype and BLRI developed native hilly chicken genotype through selective breeding. There is a general scene that the meat of native chickens is perceived to be tastier than that of exotic counterparts (Rabie $e t$ al. 2017). Thus, the price of live native chicken at the market is considerably more than that of the broiler. On the other side there is no doubt that dietary protein and energy requirements of growing chicken are variable due to many factors such as species, genotype (breed or strain), gender, growth phase, environmental temperature, housing system, plan of nutrition, diet nutrient digestibility, dietary amino acid balance and type and level of dietary fat (Mirza et al. 2014; Perween et al. 2016). Thus, there is some difficulty in the choice of optimal 
dietary crude protein and energy levels for the growing chickens that match their actual requirements in order to achieve optimal growth, superior feed conversion and the best economic efficiency and profitability (Liu et al. 2015; Miah et al. 2015). Moreover information are available on the recommended dietary crude protein and energy levels for the commercial chickens but the limited information of energy and protein level for the native chicken. The present study was undertaken to evaluate the effects of dietary energy and protein on production performance and carcass characteristics of native hilly growing chicken.

\section{Materials and Methods}

A total of 216 unsexed hilly chicks (10 weeks of age) were collected from poultry farm, poultry production research division, Bangladesh Livestock Research Institute (BLRI), Savar, Dhaka. Chickens were wing-bended and individually weighed. Based on the body weights, they were randomly assigned in to 9 treatments. Each treatment group consisted of 3 replicates of 8 hilly chicks. The treatments arranged as $3 \times 3$ factorials in completely randomized design with three crude protein levels $(16,17$ and 18\%) and three metabolizable energy levels $(2600,2700$ and $2800 \mathrm{kcal} / \mathrm{kg} \mathrm{ME})$ as shown in Table 1.

The proportion of feed ingredients and nutrient composition of the experimental diets are given in Table 2 . Feeder and waterer were cleaned daily prior to feed supply in the morning and clean water was supplied $a d$ libitum twice daily in the morning and evening. The chickens in each treatment were raised in a $2.5 \mathrm{~m}^{2}$ pen on a concrete floor in the indoor house. The initial body weights of the birds were taken at the beginning of the experiment and at weekly intervals thereafter. Feed consumption on a pen basis were weekly measured for all pens. Average daily gain, feed conversion ratio and digestibility were determined according to the procedure McDonald et al. (2011).

\subsection{Meat quality measurements}

At the end of the experiment, three chickens from each replication were randomly selected and fasted for 12 hours. Birds were slaughtered following 'halal' method (Singh et al., 2003). After evisceration, the data on hot carcass and organ weight was recorded. Breast meat from the right side was used to determine $\mathrm{pH}$, cooking loss, water holding capacity and meat color. The $\mathrm{pH}$ values of breast meat from each carcass were measured using a $\mathrm{pH}$ meter (Jenway 3510). Ten grams of meat sample was cut from the breast (pectoralis muscle) and blended with $50 \mathrm{ml}$ of distilled water (1:5 ratio) in a clean blander jar; $\mathrm{pH}$ measurements were taken at the temperature between $25-28^{\circ} \mathrm{C}$. The breast meat color was measured on the surface of samples using a chromameter (CR400, /Minolta, Japan), which was standardized using a white tile. Color for each sample was expressed in terms of Commission International de l'Eclairage values for lightness $\left(\mathrm{L}^{*}\right)$, redness $\left(\mathrm{a}^{*}\right)$ and yellowness $\left(\mathrm{b}^{*}\right)$, which was obtained using the average value of 3 measurements taken from different locations on the meat surface. A total of 162 samples 6 from each replicate (18 per treatment) were used for drip loss and cooking loss analysis.

\subsection{Statistical analysis}

Data were analyzed by the GLM procedures of SPSS software, version 20. (SPSS Inc., Chicago, IL, US) as a 3 $\times 3$ factorial arrangement with $\mathrm{CP}$ and $\mathrm{ME}$ as the main effects. The model used to analyze the data was as follows:

$\mathrm{Y}_{\mathrm{ij}}=\mu+\alpha_{\mathrm{i}}+\beta_{\mathrm{j}}+(\alpha \beta)_{\mathrm{ij}}+\varepsilon_{\mathrm{ij}}$

where $\mathrm{Y}_{\mathrm{ij}}=$ individual observation,

$\mu=$ the overall mean,

$\alpha_{\mathrm{i}}=$ dietary ME effect,

$\beta_{\mathrm{i}}=$ dietary CP effect,

$(\alpha \beta)_{\mathrm{ii}}=$ interaction effect between ME and CP,

$\varepsilon_{\mathrm{ij}}=$ error component.

If differences in treatment means were detected by ANOVA, Duncan's multiple range tests was used to separate means. The dependent variables included individual parameter (like; body weight, feed intake, FCR, carcass weight etc.).

\section{Results and Discussion}

\subsection{Growth performance}

The effect of different dietary levels of protein and energy on body weight, feed intake, weight gain and feed conversion ratio are shown in Table 3. These results shows that dietary protein and energy level had no 
significant ( $p>0.05$ ) effects on body weight, feed intake, weight gain and feed conversion ratio. Result from this study demonstrate that chicken fed with low protein diet 16\% CP tended to have better FCR (3.8) compared with those of 17\% CP (4.1) and 18\% CP (4.1). A Buakeeree and Nualhnuplong (2016) who studied in early growing period of female Betong chicken fed with $14 \%, 16 \%$ and $18 \% \mathrm{CP}$ and found that high protein (18\%) diet have better FCR (7.10) compared with those of $16 \%$ (7.21) and 14\% CP (7.73). The results of studies by Yung et al. (2001), Wu et al. (2005) and Folorunso and Onibi (2012) too agree with the observation of this study. They reported that the chicken fed varying dietary crude protein level diets had no significant effect on FCR. However, the results obtained by Pfeffer et al. (2000) and Shawangizaw et al. (2011) differed from the present study, who reported that the varying crude protein levels in diets significantly affected FCR. In this study the result shows that there was no significant effect of ME on FCR. This result obtained by Nguyen et al. (2010) agreement with this study, who reported that in growing period dietary energy content did not affect FCR. The present study results show that feed intake is lower at $17 \% \mathrm{CP}$ and $2700 \mathrm{Kcal} / \mathrm{kg} \mathrm{ME}$ level and not significant and body weight gain numerically low at $2700 \mathrm{kcal} \mathrm{ME}$ and $17 \% \mathrm{CP}$ level compared with other ME and CP level but FCR lower (3.9) at $2800 \mathrm{kcal} \mathrm{ME} \mathrm{diet} \mathrm{compared} \mathrm{with} \mathrm{other} 2600 \mathrm{kcal} \mathrm{ME} \mathrm{(4.0)} \mathrm{and} 2700 \mathrm{kcal}$ ME (4.2) respectively. This difference could be due to both genetic and non-genetic factors of experimental animals used (Banerjee et al., 2013). The present study showed that there was no significant effect of protein and energy levels on body weight and body weight gain. Body weight gain was lower for birds offered diets containing $17 \%(615 \mathrm{~g})$ and $18 \%(625 \mathrm{~g})$ protein in comparison to those offered the diets containing $16 \%(682 \mathrm{~g})$ protein. Body weight gain and feed conversion ratio (FCR) found better in $16 \% \mathrm{CP}$ level (682 $\mathrm{g}$ and 3.8). These results were supported by Buakeeree and Nualhnuplong (2016), who point that there was no significant ( $>0.05$ ) effect of CP on body weight and body weight gain. They also report that there was no significant interaction ( $p>0.05$ ) between protein and energy on average body weight and body weight gain of female Betong chicken at growing phase. There was found significant effect of dietary ME on energy $(p<0.001)$, protein intake $(p<0.05)$ and PCR.. This result agree with the result of Nguyen and Bunchasak (2005) who gound that dietary proteins affected protein intake and caused the improvement of reduced protein utilization. Nguyen and Bunchasak (2005) found that energy contents ( 3000 and $3200 \mathrm{ME} \mathrm{kcal} / \mathrm{kg}$ ) had no effect on body weight, body weight gain, feed intake and FCR of early growing chicken. Magala et al. (2012) found that dietary energy level (2800, 2900 and $3000 \mathrm{kcal} / \mathrm{kg}$ ) had no effect on growth performance of Ugandan cockerels from 8-16 weeks of age.

\subsection{Nutrient digestibility}

The effects of feeding diets differing in crude protein and energy levels on nutrient digestibility of 16 weeks old hilly cockerels were given in Table 4 . Dietary protein and energy level did not significantly affect $(p>0.05)$ the digestibility coefficient of dry matter, crude protein, fat and crude fiber.

This results obtained by Ghazalah et al. (2006) who reported that dietary protein levels had no significant effect on digestibility coefficient of crude protein, ether extract, crude fiber or nitrogen free extract in broiler chicks. Based on the results obtained in this study the nutrient digestibility of poultry diet can be influenced by various factors such as feed ingredients, dietary energy level, source of dietary fat, type of dietary carbohydrates, genotype, gender, age and role of intestinal microflora, heat stress, lack of water and diseases and any other factors that may directly or indirectly affect the digestion, absorption and/or availability of nutrients (Rabie $e t$ al., 2017). Dietary energy level did not significantly ( $>0.05)$ affect nutrient digestibility and this results also agreed with the results of Rabie et al. (2017). The interactions between dietary protein and energy levels were not significant for all nutrient metabilizability parameters measured in this study. The lack of effect of dietary protein by energy levels interaction on nutrient digestibility and utilization may indicate that both factors were not interrelated (Rabie et al., 2017).

\subsection{Carcass characteristics}

Carcass characteristics of 16 weeks old hilly cockerels as affected by dietary protein and energy levels are illustrated in Table 5. Results shows that dietary protein level had no significant effect $(p>0.05)$ on carcass traits of hilly chicken. The results agree with those of Magala et al. (2012), who observed no significant effects in carcass yield and slaughter traits of 16 weeks old Ugandan cockerels due to dietary protein level (15-17\%). Carcass yield is affected by a number of factors including genetic, feed, slaughtering condition, live weight and sex (Havenstein et al., 2003; Brickett et al., 2007). Similar results were acquired by Girish and Payne (2013), who found that dietary protein level did not affect breast yield but abdominal fat increased in broiler chicken fed the low protein diets compare to those fed the high protein diets. No effect on carcass percentage, wing, gizzard and liver weight is in agreement with the report of Nguyen and Bunchasak (2005) who found that the carcass yield of Betong native chickens was not affected by the varying dietary protein levels from 17\% to $23 \%$. 
Contradictory results showed, Kamran et al. (2004) fed different CP levels 20, 21, 22 and 23\% with energy to protein ratios of $139,146.5,152.4$ and 160 from day old to 42 days old broiler chicks and reported that breast meat yield, abdominal fat and composition of breast meat were affected by dietary protein level. On the other hand, Rabie et al. (1997), found that dietary protein level increasing from $18-20 \%$ in grower and finisher of broilers produced significant increase in breast meat yield and thigh meat yield but abdominal fat was significantly decreased.

In Table 5, dietary energy level did not significantly ( $p>0.05$ ) affect carcass, wing, abdominal fat and giblets (liver, heart and gizzard) except breast and thigh meat. Result shows that breast and thigh percentage were significantly $(\mathrm{p}<0.05, \mathrm{p}<0.001)$ higher with the increasing of energy $(2800 \mathrm{kcal} / \mathrm{kg} \mathrm{ME})$ intake. These results contrary with the result of Kamran et al. (2008) who showed that carcass yield, breast meat yield, thigh yield, abdominal fat and relative liver and heart weights did not differ when broilers were fed diets varying from 2717 to $3146 \mathrm{kcal} \mathrm{ME} / \mathrm{kg}$ and 19 to $22 \% \mathrm{CP}$ during the finishing phase. The dietary proteins by energy interaction were not significant for all carcass traits measured in this study. These results are agreed with Rabie et al. (2017) who found that the interaction of protein by energy was not significant effect on carcass traits. This observation may indicate that each dietary factor acted independently from the other (Rabie et al., 2017).

\subsection{Meat quality}

The mean lightness $\left(\mathrm{L}^{*}\right)$, redness $\left(\mathrm{a}^{*}\right)$ and yellowness $\left(\mathrm{b}^{*}\right)$ values, $\mathrm{pH}$, drip loss and cooking loss for the breast muscle of hilly chicken are presented in Table 6 . In the present study there was no effect of dietary $\mathrm{CP}$ and $\mathrm{ME}$ ( $p>0.05$ ) on $\mathrm{pH}$ in breast meat of hilly chicken. The ranges of $\mathrm{pH}$ value of all treatments are 5.78-5.83 and these ranges indicate that the $\mathrm{pH}$ value of breast meat of hilly chicken is higher quality. In this study numerically higher $\mathrm{pH}$ observe in $2700 \mathrm{kcal} / \mathrm{kg}$ ME diet compared to other treatments. Husak et al. (2008) reported that higher meat $\mathrm{pH}$ is more effective for retaining desirable color and moisture absorption properties.

In this study dietary energy and protein level did not significantly ( $p>0.05)$ affect the drip loss and cooking loss of breast meat between the treatments. There was no interaction between different dietary energy and protein on the performance of meat quality. This result agreement with the results reported by Widyatne and Drew (2011) and Min et al. (2012), who found that there was no effect of dietary CP on WHC in breast meat.

The color coordinates of the breast meat of hilly chickens fed different dietary energy and protein are presented in Table 6. There were no significant differences ( $>>0.05$ ) among birds fed different ME and CP levels and their interaction also. This observation corroborates the findings of Niu et al. (2009), who fed the broiler chicks at 20, 21, 22 and $23 \% \mathrm{CP}$ and 12.13, 12.55, $12.97 \mathrm{MJ} / \mathrm{kg}$ diets and found lightness $\left(\mathrm{L}^{*}\right)$ and yellowness $\left(\mathrm{b}^{*}\right)$ of breast meat was not affected but redness $\left(\mathrm{a}^{*}\right)$ of breast meat increased with increasing dietary ME and CP which is contrary result with the present findings. Usually, the contradictions in the scientific literature on the responsiveness of meat color is influenced by animal related factors mainly the genotype (Fletcher, 1995) and the age of animals (Fanatico et al., 2006b).

Table 1. Dietary treatments for the experiment.

\begin{tabular}{lll}
\hline Diet & & Diet description \\
\hline & ME (Kcal/kg) & Protein $(\%)$ \\
\cline { 2 - 3 }$D_{1}$ & 2600 & 16 \\
$D_{2}$ & 2600 & 17 \\
$D_{3}$ & 2600 & 18 \\
$D_{4}$ & 2700 & 16 \\
$D_{5}$ & 2700 & 17 \\
$D_{6}$ & 2700 & 18 \\
$D_{7}$ & 2800 & 16 \\
$D_{8}$ & 2800 & 17 \\
$D_{9}$ & 2800 & 18 \\
\hline
\end{tabular}


Table 2. Ingredients and nutrient composition of experimental diets.

\begin{tabular}{|c|c|c|c|c|c|c|c|c|c|}
\hline \multirow[t]{2}{*}{ Ingredients } & \multicolumn{9}{|c|}{ Treatments Diets (kg) } \\
\hline & $T_{1}$ & $\mathbf{T}_{2}$ & $T_{3}$ & $\mathbf{T}_{4}$ & $T_{5}$ & $T_{6}$ & $\mathbf{T}_{7}$ & $T_{8}$ & $T_{9}$ \\
\hline Maize & 31.1 & 32 & 33.1 & 44.7 & 44.6 & 47.2 & 56 & 55.3 & 56.2 \\
\hline Rice polish & 19.5 & 19.5 & 16.3 & 13.2 & 13 & 10 & 13 & 11.8 & 9.2 \\
\hline Wheat bran & 15.6 & 14.25 & 13.55 & 10.65 & 10.65 & 10.56 & 9.55 & 9.35 & 7.05 \\
\hline Broken rice & 14.5 & 11.5 & 11.2 & 10 & 8 & 5.6 & 0 & 0 & 0 \\
\hline Soybean meal & 9.55 & 11.8 & 14.4 & 10 & 12.5 & 16 & 9.5 & 11.6 & 15 \\
\hline Mustered oil cake & 6.8 & 8 & 8.8 & 8.2 & 8.5 & 7.8 & 8.8 & 9.6 & 10.2 \\
\hline Lime stone & 1.5 & 1.5 & 1.2 & 1.4 & 1.4 & 1.5 & 1.4 & 1.4 & 1.4 \\
\hline Di calcium phosphate & 0.5 & 0.5 & 0.5 & 0.9 & 0.4 & 0.3 & 0.8 & 0 & 0 \\
\hline Vitamin mineral premix & 0.5 & 0.5 & 0.5 & 0.5 & 0.5 & 0.5 & 0.5 & 0.5 & 0.5 \\
\hline Lysine & 0.1 & 0.1 & 0.1 & 0.1 & 0.1 & 0.1 & 0.1 & 0.1 & 0.1 \\
\hline Methionine & 0.1 & 0.1 & 0.1 & 0.1 & 0.1 & 0.1 & 0.1 & 0.1 & 0.1 \\
\hline Salt & 0.5 & 0.5 & 0.5 & 0.5 & 0.5 & 0.5 & 0.5 & 0.5 & 0.5 \\
\hline Total & 100 & 100 & 100 & 100 & 100 & 100 & 100 & 100 & 100 \\
\hline \multicolumn{10}{|l|}{ Nutrient composition } \\
\hline $\mathrm{ME}(\mathrm{kcal} / \mathrm{kg})$ & 2602 & 2609 & 2603 & 2700 & 2707 & 2701 & 2811 & 2801 & 2804 \\
\hline $\mathrm{CP}(\%)$ & 16.07 & 17.08 & 18.03 & 16.06 & 17.06 & 18.03 & 16.08 & 17.0 & 18.08 \\
\hline CF $(\%)$ & 4.32 & 3.66 & 6.27 & 4.73 & 6.41 & 5.11 & 6.12 & 6.21 & 4.85 \\
\hline $\mathrm{Ca}(\%)$ & 0.74 & 1.10 & 0.98 & 0.78 & 0.79 & 0.77 & 0.77 & 0.66 & 0.61 \\
\hline $\mathrm{P}(\%)$ & 0.34 & 0.69 & 0.54 & 0.37 & 0.53 & 0.27 & 0.36 & 0.35 & 0.32 \\
\hline Lysine (\%) & 0.79 & 0.86 & 0.92 & 0.79 & 0.85 & 0.92 & 0.77 & 0.83 & 0.91 \\
\hline Methionine (\%) & 0.36 & 0.38 & 0.39 & 0.37 & 0.38 & 0.40 & 0.37 & 0.38 & 0.40 \\
\hline
\end{tabular}

Supplied the following per kilogram of feed: vitamin A, 6250IU, vitamin D3, $1250 \mathrm{IU}$, vitamin E, 10mg, vitamin K3, $1.5 \mathrm{mg}$, vitamin B1, 5mg, vitaminB2, $2.5 \mathrm{mg}$, vitaminB6, $0.5 \mathrm{mg}$, vitamin B12, $2.5 \mathrm{mg}$, niacin, $5.625 \mathrm{mg}$, pantothenic acid, $0.3 \mathrm{mg}$, choline chloride, $50 \mathrm{mg}$, iron, $18.75 \mathrm{mg}$, copper, $3 \mathrm{mg}$, manganese, $37.5 \mathrm{mg}$, zinc, $31.25 \mathrm{mg}$, iodine, $5 \mathrm{mg}$ and selenium, $0.0625 \mathrm{mg}$

Table 3. Performance characteristics of native chicken fed of different level of energy and protein in the diets $(n=216)$.

\begin{tabular}{|c|c|c|c|c|c|c|c|}
\hline Factors & $\begin{array}{l}\text { Final body } \\
\text { weight (g) }\end{array}$ & $\begin{array}{l}\text { Body } \\
\text { weight } \\
\text { gain }(g)\end{array}$ & $\begin{array}{l}\text { Feed intake } \\
\text { (g) }\end{array}$ & $\begin{array}{l}\text { FCR } \\
\text { Feed: } \\
\text { gain }\end{array}$ & $\begin{array}{l}\text { ME intake } \\
\text { (Kcal/b) }\end{array}$ & $\begin{array}{l}\text { CP } \\
\text { intake } \\
(\mathrm{g} / \mathrm{b}) \\
\end{array}$ & $\begin{array}{l}\text { PCR } \\
\text { (protein: } \\
\text { gain) }\end{array}$ \\
\hline \multicolumn{8}{|l|}{$\mathrm{ME}(\mathrm{kcal} / \mathrm{kg})$} \\
\hline 2600 & 1563 & 646 & 2575 & 4.0 & $8405^{\mathrm{b}}$ & 533 & 0.80 \\
\hline 2700 & 1608 & 615 & 2568 & 4.2 & $8817^{\mathrm{b}}$ & 530 & 0.84 \\
\hline 2800 & 1642 & 662 & 2582 & 3.9 & $9154^{\mathrm{a}}$ & 538 & 0.84 \\
\hline \multicolumn{8}{|l|}{$\mathrm{CP}(\%)$} \\
\hline 16 & 1642 & 682 & 2580 & 3.8 & 533 & $498^{\mathrm{b}}$ & $0.78^{\mathrm{b}}$ \\
\hline 17 & 1551 & 615 & 2548 & 4.1 & 530 & $535^{\mathrm{ab}}$ & $0.85^{\mathrm{a}}$ \\
\hline 18 & 1620 & 625 & 2596 & 4.1 & 538 & $568^{\mathrm{a}}$ & $0.85^{\mathrm{a}}$ \\
\hline \multirow[t]{2}{*}{ SEM } & 17.90 & 12.10 & 12.11 & 0.071 & 54.2 & 0.02 & 0.02 \\
\hline & & & \multicolumn{5}{|l|}{$P$ value } \\
\hline \multicolumn{8}{|c|}{ Main effects \& interaction } \\
\hline $\mathrm{ME}$ & 0.231 & 0.294 & 0.899 & 0.283 & 0.000 & 0.236 & 0.281 \\
\hline $\mathrm{CP}$ & 0.120 & 0.078 & 0.282 & 0.094 & 0.254 & 0.000 & 0.043 \\
\hline $\mathrm{ME} \times \mathrm{CP}$ interaction & 0.549 & 0.943 & 0.546 & 0.881 & 0.311 & 0.308 & 0.440 \\
\hline
\end{tabular}


Table 4. Nutrient digestibility of hilly chicken fed nine regimes of energy and protein percentage (n=54)

\begin{tabular}{|c|c|c|c|c|}
\hline \multicolumn{5}{|c|}{ Parameter (\%) } \\
\hline Factors & DM & $\mathbf{C P}$ & Fat & Fiber \\
\hline ME (kcal/kg) & & & & \\
\hline 2600 & 80.68 & 73.24 & 68.27 & 21.62 \\
\hline 2700 & 79.74 & 73.34 & 69.61 & 20.52 \\
\hline 2800 & 78.96 & 72.90 & 67.70 & 21.62 \\
\hline $\mathrm{CP}(\%)$ & & & & \\
\hline 16 & 80.12 & 73.23 & 69.81 & 21.60 \\
\hline 17 & 78.29 & 71.45 & 68.11 & 21.31 \\
\hline 18 & 80.97 & 74.80 & 67.65 & 20.86 \\
\hline SEM & 0.444 & 0.657 & 0.381 & 0.601 \\
\hline & & $\mathrm{Pv}$ & & \\
\hline Main effects \& Interaction & & & & \\
\hline$\overline{\mathrm{ME}}$ & 0.307 & 0.959 & 0.140 & 0.693 \\
\hline $\mathrm{CP}$ & 0.066 & 0.143 & 0.078 & 0.881 \\
\hline $\mathrm{ME} \times \mathrm{CP}$ interaction & 0.981 & 0.586 & 0.718 & 0.988 \\
\hline
\end{tabular}

$\mathrm{DM}=$ Dry Matter, $\mathrm{CP}=$ Crude Protein, $\mathrm{ME}=$ Metabolizable Energy

Table 5. Effect of diet on carcass characteristics of hilly chicken $(n=81)$.

\begin{tabular}{|c|c|c|c|c|c|c|c|c|}
\hline \multicolumn{9}{|c|}{ Parameter (\%) } \\
\hline Factors & Carcass & $\begin{array}{l}\text { Breast } \\
\text { meat }\end{array}$ & $\begin{array}{l}\text { Thigh } \\
\text { meat }\end{array}$ & $\begin{array}{l}\text { Wing } \\
\text { meat }\end{array}$ & $\begin{array}{l}\text { Abdominal } \\
\text { fat }\end{array}$ & Liver & Heart & Gizzard \\
\hline ME (kcal/kg) & & & & & & & & \\
\hline 2600 & 64.39 & $17.04^{\mathrm{b}}$ & $9.99^{\mathrm{b}}$ & 7.78 & 0.26 & 1.75 & 0.40 & 2.6 \\
\hline 2700 & 63.71 & $17.40^{\mathrm{b}}$ & $9.96^{\mathrm{b}}$ & 7.67 & 0.28 & 1.74 & 0.39 & 2.5 \\
\hline 2800 & 64.64 & $18.71^{\mathrm{a}}$ & $10.64^{\mathrm{a}}$ & 7.93 & 0.16 & 1.78 & 0.40 & 2.4 \\
\hline $\mathrm{CP}(\%)$ & & $-=-[$ & & & & & & \\
\hline 16 & 64.39 & 17.63 & 10.12 & 7.78 & 0.19 & 1.83 & 0.42 & 2.6 \\
\hline 17 & 64.25 & 17.35 & 10.42 & 7.94 & 0.21 & 1.75 & 0.41 & 2.5 \\
\hline 18 & 64.10 & 18.16 & 10.05 & 7.66 & 0.31 & 1.69 & 0.38 & 2.4 \\
\hline SEM & 0.332 & 0.225 & 0.094 & 0.055 & 0.035 & 0.028 & 0.009 & 0.060 \\
\hline & & & \multicolumn{2}{|c|}{$P$ value } & & & & \\
\hline \multicolumn{9}{|c|}{ Main effects \& Interaction } \\
\hline ME & 0.490 & 0.012 & 0.007 & 0.176 & 0.296 & 0.815 & 0.847 & 0.251 \\
\hline $\mathrm{CP}$ & 0.940 & 0.353 & 0.234 & 0.135 & 0.354 & 0.112 & 0.205 & 0.673 \\
\hline $\begin{array}{l}\mathrm{ME} \times \mathrm{CP} \\
\text { interaction }\end{array}$ & 0.941 & 0.733 & 0.247 & 0.067 & 0.897 & 0.135 & 0.347 & 0.985 \\
\hline
\end{tabular}

$\stackrel{a, b, c}{a}$ means on the same column with different superscripts differ significantly $(\mathrm{p}<0.05),(\mathrm{P}<0.001)$

$\mathrm{ME}=$ Metabolizable Energy, $\mathrm{CP}=$ Crude Protein 
Table 6. Effects of various levels of energy and protein in the diets on meat quality of hilly chicken ( $n=54)$.

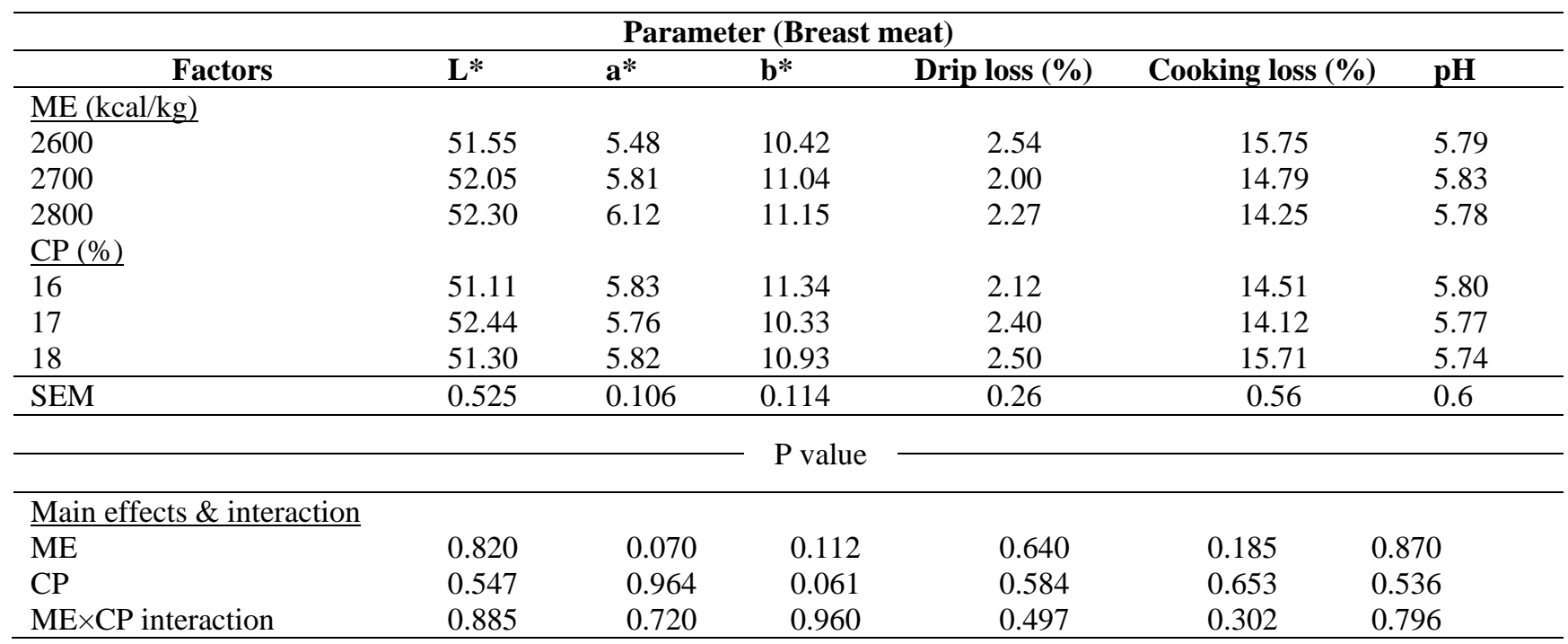

$\mathrm{ME}=$ Metabolizable Energy, $\mathrm{CP}=$ Crude Protein

L*: Lightness; $a^{*}$ : Redness; $b^{*}$ : Yellowness

\section{Conclusions}

In general, based on the data of growth performance, carcass characteristics and meat quality, it was indicate that the optimal dietary ME requirement of hilly chicken from 10-16 weeks of age is $2800 \mathrm{ME} \mathrm{kcal} / \mathrm{kg}$ and the $\mathrm{CP}$ requirement is $16 \%$.

\section{Conflict of interest}

None to declare.

\section{References}

Banerjee S, A Melesse, E Dotamo, K Berihun and M Beyan. 2013. Effect of different dietary protein levels with iso-caloric ration on nutrients intake and growth performance of duo-purpose koekoeck chicken breeds. International Journal of Applied Poultry Research, 2: 27-55.

Brickett KE, JP Dahiya, HL Classen and S Gomis. 2007. Influence of dietary nutrient density, feed form and lighting on growth and meat yield of broiler chickens. Poult. Sci., 86: 2172-2181.

Buakeeree K and P Nualhnuplong. 2016. Effects of dietary protein and energy levels on growth performances and reproductive system development in female Betong chicken (Gallus domesticus) during growing pullet period. Khon Kean Agr. J., 44: 469-478.

Carlson IR, 1969. Growth regulators in animal growth and nutrition. Eds Hafez, ESE and Dryer, I A Publishers Lea and Febiger, Philadelphia, USA. pp. 138-155.

Collin A, RD Malheiros, VMB Moraes, VA Pieter, VM Darras, M Taouis, E Decuypere and J Buyse. 2003. Effects of dietary macronutrient content on energy metabolism and uncoupling protein mRNA expression in broiler chickens. British Journal Nutrition, 90: 261-269.

Fanatico A, CPB Pillai, LC Cavitt, CM Owens and JL Emmert, 2006b. Evaluation of slower growing broiler genotypes grown with and without outdoor access: Growth performance and carcass yield. Poult. Sci., 84: 1321-1327.

Fletcher DL, 1995. Relationship of breast meat color variation to muscle pH and texture. Poult. Sci.74 (Supp. 1): 120 (Abstr.).

Folorunso OR and GE Onibi, 2012. Effect of diets of different protein levels fed on dry or wet forms on the performance and carcass characteristics of broiler chicken finishers. Int. J. Agric. Sci., 2: 538-545.

Ghazalah AA, El-Nagmy and AS Bahakin. 2006. Response of broiler chicks to low protein diets supplemented with probiotics preparations. Egypt. Poult. Sci., 26: 609-627.

Girish CK and RL Payne, 2013. Effect of varying dietary metabolizable energy and protein on performance of broiler chickens. Proceedings of the $24^{\text {th }}$ Annual Australian Poultry Science Symposium, February 17-20, 2013, Sydney, New South Wales, Australia. Pp: 122-125. 
Havenstein GB, PR Ferket and MA Qureshi. 2003. Carcass composition and yield of 1957 versus 2001 broilers when fed representative 1957 and 2001 broiler diets. Poult Sci., 82: 1509-1518.

Kamran Z, M Sarwar, M Nisa, MA Nadeem, S Mahmood, ME Babar and S Ahmed. 2004. Effect of LowProtein Diets Having Constant Energy-to-Protein Ratio on Performance and Carcass characteristics of Broiler Chickens from One to Thirty-Five Days of Age. Poult. Sci., 87: 468-474.

Leenstra FR, 1989. Influence of diet and genotype on carcass quality in poultry, and their consequences for selection. Recent developments in poultry nutrition. London: Butter worths. 131-144.

Liu SK, YZ Niu, NY Min, PZ Wang and J Zhang, 2015. Effects of dietary crude protein on the growth performance, carcass characteristics and serum biochemical indexes of Lueyang Black-boned chickens from seven to twelve weeks of age. Rev. Bras. Cienc. Avic.,17: 103-108.

Magala H, DR Kugonza, H Kwizera and CC Kyarisiima. 2012. Influence of varying dietary energy and protein on growth and carcass characteristics of Ugandan local local chicken. J Anim. Sci. Adv., 2: 558-567.

Marks HL, 1990. Genotype by diet interactions in body and abdominal fat weight in broilers. Poult. Sci., 69: 879-886.

McDonald P, RA Edwards, JFD Greenhalgh, CA Morgan, LA Sinclair and RG Wilkinson, 2011. Animal Nutrition, Seventh edition, Prentice Hall London.

Miah MY, SD Chowdhury and AKFH Bhuiyan, 2015. Effect of diets of different protein concentrations on Indigenous growing chicks of Bangladesh in confinement. Asian. J. Med. Bio. Res., 1: 109-113.

Min YN, JS Shi, FX Wei, HY Wang, XF Hou, ZY Niu and FZ Liu, 2012. Effects of dietary energy and protein on growth performance and carcass quality of broilers during finishing phase. Journal of Animal and Veterinary Advances, 11: 3652-3657.

Mirza MA, R Kausar and T Ahmad. 2014. Effect of dietary energy to protein ratio on the growth of male broilers kept under oppressively hot climatic conditions. Pak. J. Agric. Sci., 51: 1081-1084.

Nguyen VT and C Bunchasak, 2005. Effect of dietary protein energy on growth performance and carcass characteristics of Betong chicken at early growth stage. Songklanakarin J. Sci. Technol., 27: 1171-1178.

Nguyen VT, C Bunchasak and S Chantsavang, 2010. The effects of dietary protein and energy on growth performance and carcass characteristics of Betong chickens (Gallus domesticus) during growing period. Int. J. Poult. Sci., 9: 468-472.

Niu ZY, SJ Shi, ZF Liu, HX Eang, QC Gao, KL Yao, 2009. Effects of dietary energy and protein on growth performance and carcass quality of broiler during starter phase. Int. J. Poult. Sci., 8: 508-511.

Northcutt JK, EA Foegeding and Edens, 1994. Water-holding properties of thermally preconditioned chicken breast and leg meat. Poult. Sci., 73: 308-316.

Perween S, K Kumar, S Chandramoni, P Kumar, K Singh, M Kumar and A Dey, 2016. Effect of feeding different dietary levels of energy and protein on growth performance and immune status of Vanaraja chicken in the tropic. Vet. World., 9: 893-899.

Pfeffer E, VA Altor and II Hamid, 2000. Low protein amino acids supplemented diets in broiler chickens: effect on performance, carcass characteristics, whole body composition and efficiency of nutrient utilization. J. Sci. Food Agric., 80: 447-554.

Rabie MH, KhEl Sherif, AM Abd El- Khalek and AAA El-Gamal, 2017. Effect of dietary energy and protein on growth performance and carcass traits of Mamourah cockerels. Asian Journal of Animal and Veterinary Advances, 12: 142-151.

Rabie MH, M Szilagyi and T Gippert, 1997. Effects of dietary L-carnitine supplementation and protein level on performance of meatness and fatness of broilers. Acta Biol. Hung., 48: 221-239.

Rizz C, A Marangon and GM Chierica, 2007. Effect of genotype on slaughtering performance and meat physical and sensory characteristics of organic laying hens. Poul. Sci., 86: 128-135.

Shawangizaw W, T Negesse and A Melesse, 2011. The effect of dietary protein concentration on nutrient utilization of Rhode Island Red chicken in Wolaita (South Ethiopia). Tropic Subtropic Agroecosyst, 14: 271278.

Singh DP, S Rajvir and MC Kataria, 2003. Conservation and utilization of indigenous fowl. In: Annual Report of Central Avian Research Institute, 2002-03. pp. 18.

SPSS, 2015. Statistical Package for the Social Sciences. Statistics version 20.0 IBM SPSS Inc., USA.

Swennen Q, GP Janssens, A Collin, LeE Bihan-Duval, K Verbeke, E Decuypere and J Buyse, 2006. Dietinduced thermo genesis and glucose oxidation in broiler chickens: Influence of genotype and diet composition. Poult. Sci., 85: 731-742.

Widyaratne GP and MD Drew, 2011. Effects of protein level and digestibility on the growth and carcass characteristic of broiler chickens. Poult. Sci., 90: 595-603. 
Wiseman J, 1987. Meeting nutritional requirement from available resources. In: feeding of non-ruminant animals. Translated and ed. By J. Wiseman. Butter worth and C. Ltd. pp. 9-15.

Wu G, MM Bryant, RA Voitle and DA Roland, 2005. Effect of dietary energy on performance and egg composition of bovans white and dekalb white hens during phase. Int. Poult. Sci., 84: 1610-1615.

Yung LC, C Chuanhuang, C Yenghow, H Jennchung, C Mingtasao and L Dengcheng, 2001. Effects of different dietary protein and energy levels in the growth performance, blood characteristics and sensory panels of caponized Taiwan country chicken cockerels during finishing period. J. Chinese Soc. Anim. Sci., 30: 81-91. 